\section{Postharvest Quality of Grape Tomatoes Treated with 1-Methylcyclopropene at Advanced Ripeness Stages}

\author{
Muharrem Ergun, ${ }^{1}$ Steven A. Sargent, ${ }^{2}$ and Donald J. Huber \\ Horticultural Sciences Department, University of Florida, Institute of Food \\ and Agricultural Sciences, P.O. Box 110690, Gainesville, FL 32611-0690
}

Additional index words. Lycopersicon esculentum Mill., 1-MCP, respiration, ethylene, ripening, storage, specialty tomato

\begin{abstract}
Grape tomatoes (Lycopersicon esculentum Mill. 'Santa') harvested at light-red $\left(>90 \%\right.$ color) and full-red stages were treated with $1 \mu \mathrm{L} \cdot \mathrm{L}^{-1} 1$-methylcyclopropene (1MCP) for 24 hours at $20^{\circ} \mathrm{C}$ and stored at $20^{\circ} \mathrm{C}$. After 1 day of storage, fruit harvested at light-red stage treated with 1-MCP had a 56\% lower respiration rate than untreated fruit. By day 7, respiration rates of the two treatments had converged at about $2 \mathrm{~mL} \cdot \mathrm{kg}^{-1} \cdot \mathbf{h}^{-1}$. Ethylene production of light-red stage tomatoes treated with 1-MPC was $24 \%$ lower than untreated during storage, with rates converging by day 11 . For fruit harvested full-red, 1-MCP had similar effects on respiration and ethylene production, although convergence occurred earlier, by day 5 . Subsequent tests were conducted only with fruit harvested at full-red stage, since fruit harvested at the light-red stage had lower soluble solids content $(4.3 \%)$ than fruit harvested at the full-red stage (5.5\%). Several combinations of 1-MCP concentrations and exposure times were applied at $20^{\circ} \mathrm{C}: 1 \mu \mathrm{L} \cdot \mathrm{L}^{-1}$ for $24 \mathrm{~h}, 5 \mu \mathrm{L} \cdot \mathrm{L}^{-1}$ for 6 or $12 \mathrm{~h}, 25 \mu \mathrm{L} \cdot \mathrm{L}^{-1}$ for 6 or $12 \mathrm{~h}$, and $50 \mu \mathrm{L} \cdot \mathrm{L}^{-1}$ for 6 or $12 \mathrm{~h}$; following the respective pretreatment fruits were stored at $20^{\circ} \mathrm{C} .1-\mathrm{MCP}$ pretreatment extended marketable life by $1 \mathrm{~d}$, irrespective of pretreatment regime, where untreated and pretreated fruit remained marketable ( $<15 \%$ of fruit soft, decayed and/or shriveled) for 6 and $7 \mathrm{~d}$, respectively. However, 1-MCPdid not affect whole fruit firmness, epidermal color, internal color, soluble solids content $(6.5 \%)$, total titratable acidity $(0.64 \%)$, or $\mathrm{pH}(4.3)$. In a third test simulating commercial handling procedures, full-red harvested tomatoes were treated with $1 \mu \mathrm{L} \cdot \mathrm{L}^{-1}$ 1-MCP for $24 \mathrm{~h}$ at either 13 or $20^{\circ} \mathrm{C}$, stored for $4 \mathrm{~d}$ at $13{ }^{\circ} \mathrm{C}$, and then transferred to 20 ${ }^{\circ} \mathrm{C}$. Under these conditions, marketable life for untreated and 1-MCP-treated tomatoes was 7 and $8 \mathrm{~d}$, respectively.
\end{abstract}

Fresh-market round-type tomatoes (Lycopersicon esculentum) are often harvested at the green stage to minimize handling injury and to maximize postharvest life. When harvested and handled properly, these tomatoes ripen with excellent flavor (Maul et al., 2000); however, poor handling can cause tomatoes to ripen with poor flavor due to lower concentrations of sugars and organic acids (Malundo et al., 1995). Bruised tomatoes were reported to have lower flavor acceptability, and lower carotenoids, vitamin $\mathrm{C}$ and total titratable acidity relative to unbruised fruit (Moretti et al., 1997, 1998). On the other hand, fruit harvested near full-ripe or at full-ripe stage possessed maximum flavor quality. The negative side of fruit harvested full ripe is limited storage life, since extended storage leads to a decrease in acidity, softening and development of moldy aroma or off-flavor (Janse, 1995; Kader et al., 1978).

Round-type tomatoes have long dominated fresh-market sales; however, since the mid-

Received for publication 12 Sept. 2005.Accepted for publication 27 Oct. 2005. Partial support provided by the U.S. Dept. of Agriculture, Cooperative State Research, Education, and Extension Service, Tropical/Subtropical Agriculture Research Program. ${ }^{1}$ Current address: Kahramanmaras Sutcu Imam University, Department of Horticulture, Kahramanmaras, 46100, Turkey.

${ }^{2}$ Corresponding author and to whom reprint requests should be addressed; e-mail sasa@ifas.ufl.edu.
1990 s, the number of specialty tomato types has increased, notably roma, cluster, grape, and mini-pear types (Roberts et al., 2002). The increased demand for grape tomato is due to its smaller size, sweet flavor and firm texture, and has caused production of cherry tomato to significantly decrease. For example, sales of 'Santa' grape tomato were reported to have tripled during the first three months of 2003 (Ag-Mart Produce Inc., Plant City, Fla.).

Grape tomatoes are typically packed and shipped in hinged, clamshell containers. In contrast to round tomatoes which can be harvested mature green and ripened to high flavor (Maul et al., 2000), grape tomato flavor is best when the fruit is harvested at nearly full-red color (Roberts et al., 2002). Tomatoes often are shipped in mixed loads at temperatures lower than the recommended $12.5^{\circ} \mathrm{C}$ (Geeson et al., 1985), which can induce chilling injury in tomatoes at any ripening stage (Hardenburg, 1986; Maul et al., 2000). To date, postharvest information specific to specialty tomato types is almost nonexistent for growers and retailers, therefore they are handled using recommendations that were developed for round (beefstake) tomato types.

The ripening of tomato, a climacteric fruit, is tightly regulated by ethylene (Hoeberichts et al., 2002; Yang and Hoffman 1984). Ethylene synthesis and action in round-type tomatoes can be affected by application of ethylene antagonists such as silver thiosulfate, 2,5-norbornadiene, diazocyclopentadiene or 1-methylcyclopropene (1-MCP), that inhibit various ripening-related biochemical changes such as polygalacturonase (EC 3.2.1.1.15) activity, lycopene accumulation and mRNA abundance of expansin 1 (Hoeberichts et al., 2002; Liu et al., 1989; Mir et al., 2004; Mostofi et al., 2003; Sisler and Lallu, 1994; Tucker and Brady, 1987; Wills and Ku, 2002). 1-MCP is a very effective growth regulator limiting ethylene action in many fruits and vegetables (Blankenship and Dole, 2003). When applied to round-type tomatoes at advanced stages of ripening (light-red or full-red), 1-MCP temporarily interrupted the progression of ripening (Hoeberichts et al., 2002; Hurr, et al., 2005; Mir et al., 2004).

The effects of harvest maturity and storage temperature on postharvest quality of grape tomato were studied by Roberts et al. (2002), who also modified grape tomato color classification from the United States grade standards for round tomatoes (U.S. Dept. of Agriculture, 1976). During grape tomato ripening the fruit passes from an orange stage $(>90 \%$ red with translucent pericarp) to light-red stage ( $>90 \%$ red with opaque pericarp) to full-red stage $(100 \%$ red) to over-ripe (deep red as water-soaked tissue becomes visible through the epidermis).

This report describes a series of experiments designed to determine the effects of harvest maturity, 1-MCP pretreatment regime (concentration, length of exposure, temperature) and subsequent storage conditions on postharvest quality and physiological responses of grape tomatoes.

\section{Material and Methods}

Plant material and pretreatment conditions. Grape tomatoes, commercially harvested and washed with water (150 to $200 \mu \mathrm{L} \cdot \mathrm{L}^{-1}$ freechlorine), were obtained from Ag-Mart Inc., Plant City, Fla., the day of harvest. The fruit were transferred to the Postharvest Horticulture Laboratory at the University of Florida, Gainesville, and either prepared immediately for experiments or stored overnight at $13{ }^{\circ} \mathrm{C}$ and prepared the following day. The fruit were sorted for defects and selected for color as either light-red ( $>90 \%$ red color) or full-red $(100 \%$ red color) (Roberts et al., 2002) followed by treatment with 1-MCP.

1-MCP gas was prepared from SmartFresh (Agrofresh, Philadelphia, Pa.) commercial powder (active ingredient $0.14 \%$ ) and quantified by the method described by Ergun and Huber (2004). Vial-headspace gas samples (based on the required 1-MCP concentrations for each experiment) were injected into sealed, glass jars (2-L void volume), containing the tomatoes. Following the 1-MCP pretreatment for the respective experiment, the fruit were then randomized into rigid, vented clamshells (473-mL volume; $\mathrm{n}=20$ fruit/container) and stored in air. Depending on the experiment 14 to 20 clamshells per treatment were used. Treatment conditions for each of the three experiments are summarized (Table 1). 
Table 1. Ripeness stage at harvest and pretreatment/storage regimes for Expts. 1, 2, and 3.

\begin{tabular}{|c|c|c|c|c|}
\hline \multirow[b]{2}{*}{ Experiment } & \multicolumn{3}{|c|}{ Pretreatment conditions } & \multirow[b]{2}{*}{$\begin{array}{c}\text { Storage } \\
\text { temp } \\
\left({ }^{\circ} \mathrm{C}\right)\end{array}$} \\
\hline & $\begin{array}{c}1-\mathrm{MCP} \\
\text { concn } \\
\left(\mu \mathrm{L} \cdot \mathrm{L}^{-1}\right)\end{array}$ & $\begin{array}{l}\text { Exposure } \\
\text { duration } \\
\text { (h) }\end{array}$ & $\begin{array}{c}\text { Exposure } \\
\text { temp } \\
\left({ }^{\circ} \mathrm{C}\right)\end{array}$ & \\
\hline \multirow[t]{2}{*}{$\overline{1^{z}}$} & 0 (air control) & 24 & 20 & 20 \\
\hline & 1 & 24 & 20 & 20 \\
\hline \multirow[t]{9}{*}{$2^{y}$} & 0 (air control) & 24 & 20 & 20 \\
\hline & 1 & 24 & 20 & 20 \\
\hline & 5 & 6 & 20 & 20 \\
\hline & 5 & 12 & 20 & 20 \\
\hline & 25 & 6 & 20 & 20 \\
\hline & 25 & 12 & 20 & 20 \\
\hline & 5 & 12 & 20 & 20 \\
\hline & 50 & 6 & 20 & 20 \\
\hline & 50 & 12 & 20 & 20 \\
\hline \multirow[t]{4}{*}{$3^{y}$} & 0 (air control) & 24 & 13 & 13 (for $4 \mathrm{~d}$ ) then transferred to 20 \\
\hline & 0 (air control) & 24 & 20 & 13 (for $4 \mathrm{~d}$ ) then transferred to 20 \\
\hline & 1 & 24 & 13 & 13 (for $4 \mathrm{~d}$ ) then transferred to 20 \\
\hline & 1 & 24 & 20 & 13 (for $4 \mathrm{~d}$ ) then transferred to 20 \\
\hline
\end{tabular}

${ }^{\mathrm{z}}$ Fruit were harvested at light-red or full-red ripeness stages.

${ }^{y}$ Fruit were harvested only at full-red stage.

Respiration rate and ethylene production. At 2-d intervals, respiration and ethylene production were measured by sealing individual fruit in $50 \mathrm{~mL}$ glass Wheaton vials ( 5 vials per treatment) at $20^{\circ} \mathrm{C}$. After $2 \mathrm{~h}$, respiration and ethylene production was measured as described by Ergun et al. (2005).

Quality assessments. Fruit quality was assessed each $2 \mathrm{~d}$ during the first $4 \mathrm{~d}$ of storage, then daily until the end of marketable life. Individual fruits were subjectively rated for presence of absence of the primary defect (softening, shriveling or decay). Softening was determined by applying light pressure on each fruit with the thumb and forefinger, while shriveling or decay was noted upon appearance. No fruit were removed from any containers during storage. The end of marketable life for each container was defined as the point at which $>15 \%$ of the fruit within an individual container exhibited softening, shriveling and/or decay (U.S. Dept. of Agriculture, 1976). Firmness was also determined nondestructively during storage using an Instron Universal Testing Instrument (model 4411; Canton, Mass.) equipped with a 5-kg load cell and an 8-mm-diameter convex probe according to Roberts etal. (2002). The probe was positioned at zero force in contact with the fruit surface (at the equatorial region, above the locule), and driven to a depth of $2 \mathrm{~mm}$ at a crosshead speed of $50 \mathrm{~mm} \cdot \mathrm{min}^{-1}$. Firmness data were reported as the maximum force (Newton) recorded during deformation. Weight loss was determined during storage (fresh weight basis; $\mathrm{n}=5$ fruit/treatment).

Individual fruits were marked on the epidermis at the equatorial region for external color measurement (aperture $=11 \mathrm{~mm}$; CR-2000; Minolta, Japan) at the same location over time (Hobson et al., 1983). For the internal color assessment, each fruit was sliced equatorially and the reading made on the cut surface of one fruit half. The color was reported as hue angle (the dimension of color that specifies a position on a color wheel of $360^{\circ}$, in which $0^{\circ}$ $=\operatorname{red}$ and $90^{\circ}=$ yellow (McGuire, 1992). At this point the fruit halves were stored at -20 ${ }^{\circ} \mathrm{C}$ for later compositional analyses. by Ergun et al. (2005). TTA was expressed as percent citric acid equivalents.

Statistical analysis. The experiments were conducted using a randomized complete block design. Statistical procedures were performed using PC-SAS software package. All data were subject to analysis of variance, and means were compared using Duncan's multiple range test.

\section{Results}

Experiment 1. Effect of harvest maturity and 1-MCP pretreatment on postharvest quality and physiological responses. The initial respiration rate of 1-MCP-treated fruit $\left(1 \mu \mathrm{L} \cdot \mathrm{L}^{-1}\right.$ for $24 \mathrm{~h}$ at $20^{\circ} \mathrm{C}$ ) was $56 \%$ lower than that of control fruit $\left(3.8 \mathrm{~mL} \cdot \mathrm{kg}^{-1} \cdot \mathrm{h}^{-1}\right.$ and $8.5 \mathrm{~mL} \cdot \mathrm{kg}^{-1} \cdot \mathrm{h}^{-1}$, respectively) (Fig. $1 \mathrm{~A}$ ). The respiration rate of light-red harvested control fruit decreased throughout storage at $20{ }^{\circ} \mathrm{C}$, whereas that for 1-MCP-treated fruit remained fairly constant after 3-d storage. Initial respiration rates of full-red harvested fruit were similar to the respective treatments of light-red harvested fruit; however, respiration rates of the both treatments were similar during storage (Fig. 1B). On day 7, respiration rates were and total titratable acidity (TTA) as described

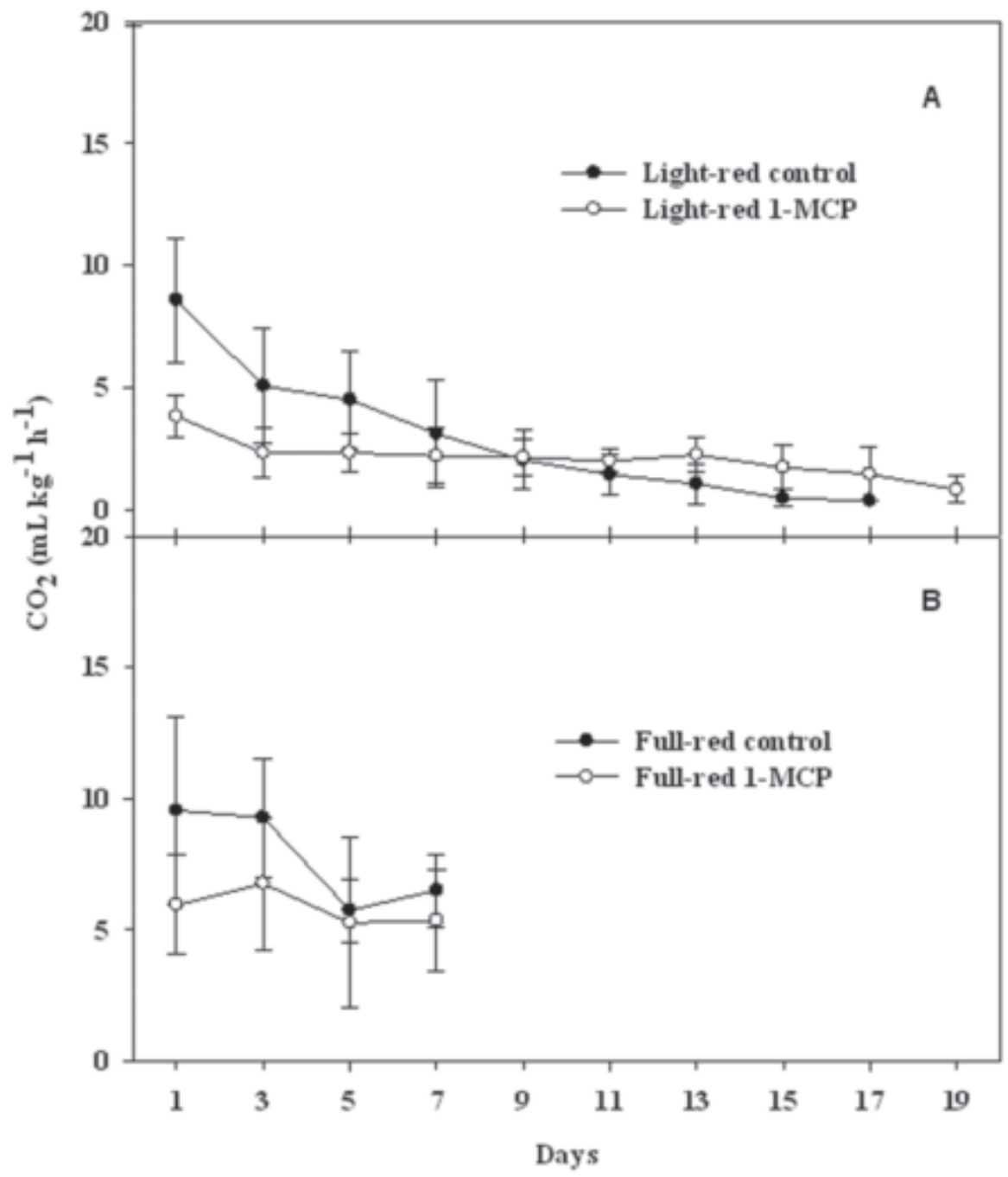

Fig. 1. Respiration rates of grape tomatoes harvested at light-red (A) and full-red (B) stages after \pm 1 -MCP pretreatment $\left(1 \mu \mathrm{L} \cdot \mathrm{L}^{-1}\right.$ for $\left.24 \mathrm{~h}\right)$ during storage at $20^{\circ} \mathrm{C}$. Vertical bars represent standard deviation (n $=5)($ Expt. 1). 
Fig. 2. Ethylene production of fruit harvested at light-red (A) and full-red (B) stages after \pm 1 MCP pretreatment $\left(1 \mu \mathrm{L} \cdot \mathrm{L}^{-1}\right.$ for $\left.24 \mathrm{~h}\right)$ during storage at $20^{\circ} \mathrm{C}$. Vertical bars represent standard deviation $(\mathrm{n}=5)($ Expt. 1).

$6.5 \mathrm{~mL} \cdot \mathrm{kg}^{-1} \cdot \mathrm{h}^{-1}$ (control) and $5.4 \mathrm{~mL} \cdot \mathrm{kg}^{-1} \cdot \mathrm{h}^{-1}$ (1-MCP pretreated).

Ethylene production of light-red harvested tomatoes was similar for both treatments, declining only slightly by day 16 (Fig. 2A). Rates declined from 13.8 to $8.2 \mu \mathrm{L} \cdot \mathrm{g}^{-1} \cdot \mathrm{h}^{-1}$ (control) and from 12.9 to $7.5 \mu \mathrm{L} \cdot \mathrm{kg}^{-1} \cdot \mathrm{h}^{-1}$ (1MCP). Initial ethylene production of full-red harvested control fruit was $>2$-fold higher $\left(12.82 \mu \mathrm{L} \cdot \mathrm{kg}^{-1} \cdot \mathrm{h}^{-1}\right)$ than that for 1-MCP fruit $\left(5.1 \mu \mathrm{L} \cdot \mathrm{kg}^{-1} \cdot \mathrm{h}^{-1}\right)$ (Fig. 2B). Ethylene production of control fruit declined to $5.1 \mu \mathrm{L} \cdot \mathrm{kg}^{-1} \cdot \mathrm{L}^{-1}$ by day 7 , while that for 1 -MCP fruit remained fairly constant.

The initial firmness for light-red harvested fruit was $3.3 \mathrm{~N}$; after pretreatment (day 1) both treatments decreased to $2.9 \mathrm{~N}$ (data not shown). During the subsequent $18 \mathrm{~d}$ of storage, firmness of tomatoes from both treatments decreased by about $20 \%$. Firmness of fruit harvested at full-red stage decreased from 3.0 to $2.7 \mathrm{~N}$ after $1-\mathrm{MCP}$ treatment and remained constant during the following $6 \mathrm{~d}$ of storage (data not shown). Grape tomatoes harvested at either ripeness stage lost weight at similar rates during storage, irrespective of pretreatment. At the end of marketable life, light-red harvested fruit and full-red harvested fruit lost $11.5 \%$ and $6.5 \%$ mass (fresh weight basis), respectively (data not shown).

Pretreatment with 1-MCP did not affect fruit color at the end of marketable life. During storage the external color (hue angle) of light-red harvested fruit decreased from $45^{\circ}$ to $39^{\circ}$ and internal color decreased from $64^{\circ}$ to $55^{\circ}$; external color of full-red harvested fruit decreased from $37^{\circ}$ to $36^{\circ}$ and internal color decreased from $56^{\circ}$ to $55^{\circ}$. Fruit harvested at full-red stage had initial soluble solids content of $5.5^{\circ}$ Brix, $28 \%$ higher than that for fruit harvested at the light-red stage $\left(4.3^{\circ} \mathrm{Brix}\right)$. TTA and $\mathrm{pH}$ were similar for fruit harvested at both ripeness stages $(0.59 \%$ and 4.4 , respectively)(data not shown). Since grape tomatoes harvested at the light-red stage had lower soluble solids content and consequently less flavor, subsequent experiments were confined to tomatoes harvested at full-red stage.

Experiment 2. Effect of several 1-MCP pretreatment regimes on postharvest quality and physiological responses. Tomatoes from all treatments were marketable after $5 \mathrm{~d}$ storage at $20^{\circ} \mathrm{C}$ (Table 2). After $6 \mathrm{~d}$ of storage control fruit had $23.2 \%$ defects and were out of grade, and after $7 \mathrm{~d}$ all 1-MCP treated tomatoes were out of grade, with total defects ranging from $27.9 \%\left(5 \mu \mathrm{L} \cdot \mathrm{L}^{-1}\right.$ for $\left.12 \mathrm{~h}\right)$ to $44.9 \%\left(25 \mu \mathrm{L} \cdot \mathrm{L}^{-1}\right.$ for $12 \mathrm{~h}$ ). In all treatments softening was the primary cause for defects, followed by decay then shriveling. Fungal decay (pathogen not identified) usually started at the stem end and spread over fruit during storage at $20^{\circ} \mathrm{C}$. At the end of marketable life ( $5 \mathrm{~d}$ for control, $6 \mathrm{~d}$ for 1 -MCP treated) there were no significant differences with respect to firmness $(2.2 \mathrm{~N})$, weight

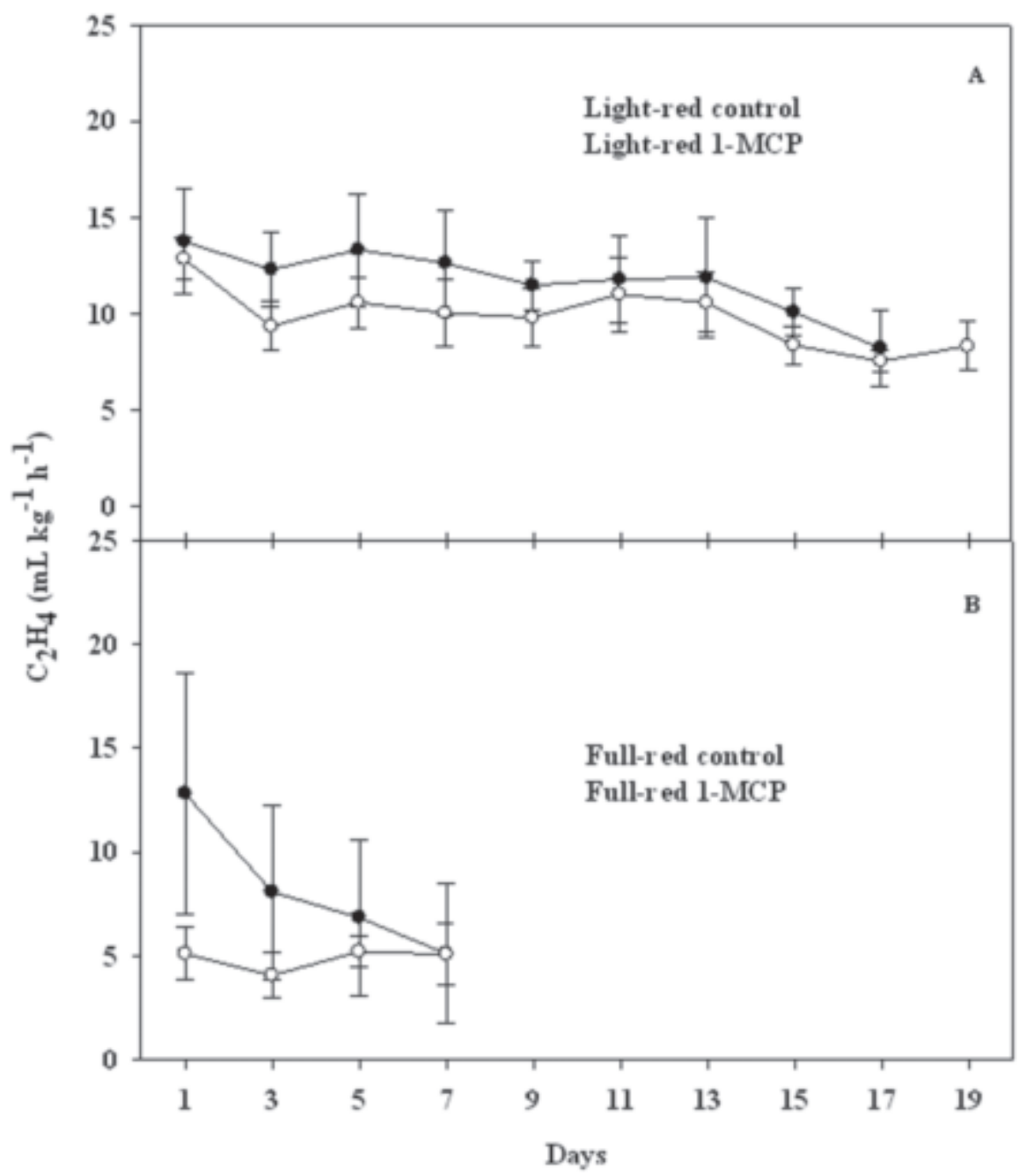

Table 2. Appearance of grape tomato defects during storage in air for several pretreatment regimes of 1MCP concentrations $\left(\mu \mathrm{L} \cdot \mathrm{L}^{-1}\right)$ and exposure durations (h) at $20{ }^{\circ} \mathrm{C}$ (Expt. 2).

\begin{tabular}{|c|c|c|c|c|c|}
\hline \multirow{2}{*}{$\begin{array}{l}\text { Storage } \\
\text { time } \\
\text { (d) }\end{array}$} & \multirow{2}{*}{$\begin{array}{c}\text { Pretreatment } \\
\text { conditions } \\
(1-\mathrm{MCP} / \mathrm{h})\end{array}$} & \multicolumn{3}{|c|}{ Defect $^{2}$} & \multirow{2}{*}{$\begin{array}{c}\text { Total } \\
\text { defects }^{y} \\
(\%)\end{array}$} \\
\hline & & $\begin{array}{l}\text { Soft } \\
(\%)\end{array}$ & $\begin{array}{c}\text { Shrivel } \\
(\%)\end{array}$ & $\begin{array}{c}\text { Decay } \\
(\%)\end{array}$ & \\
\hline \multirow[t]{8}{*}{5} & Air control & 10.0 & 0 & 0 & $10 \mathrm{a}^{\mathrm{x}}$ \\
\hline & $1 / 24$ & 5.0 & 0 & 0 & $5.0 \mathrm{c}$ \\
\hline & $5 / 6$ & 6.6 & 0 & 0 & $6.6 \mathrm{bc}$ \\
\hline & $5 / 12$ & 1.6 & 1.6 & 5.0 & $8.2 \mathrm{ab}$ \\
\hline & $25 / 6$ & 3.0 & 1.6 & 1.6 & $6.2 \mathrm{bc}$ \\
\hline & $25 / 12$ & 0 & 0 & 5.0 & $5.0 \mathrm{c}$ \\
\hline & $50 / 6$ & 0 & 0 & 5.0 & $5.0 \mathrm{c}$ \\
\hline & $50 / 12$ & 1.6 & 0 & 6.6 & $8.2 \mathrm{ab}$ \\
\hline \multirow[t]{8}{*}{6} & Air control & 15.0 & 1.6 & 6.6 & $23.2 \mathrm{a}$ \\
\hline & $1 / 24$ & 10.0 & 0 & 5.0 & $15.0 \mathrm{~b}$ \\
\hline & $5 / 6$ & 8.3 & 1.6 & 3.3 & $13.2 \mathrm{~b}$ \\
\hline & $5 / 12$ & 8.3 & 1.6 & 5.0 & $14.9 \mathrm{~b}$ \\
\hline & $25 / 6$ & 8.3 & 1.6 & 5.0 & $14.9 \mathrm{~b}$ \\
\hline & $25 / 12$ & 8.3 & 0 & 5.0 & $13.3 \mathrm{~b}$ \\
\hline & $50 / 6$ & 10.0 & 0 & 5.0 & $15.0 \mathrm{~b}$ \\
\hline & $50 / 12$ & 8.3 & 0 & 6.6 & $14.9 \mathrm{~b}$ \\
\hline \multirow[t]{8}{*}{7} & Air control & --- & --- & --- & --- \\
\hline & $1 / 24$ & 21.0 & 0 & 10.0 & $31.0 \mathrm{~cd}$ \\
\hline & $5 / 6$ & 25.0 & 3.3 & 8.3 & $36.6 \mathrm{bc}$ \\
\hline & $5 / 12$ & 18.0 & 1.6 & 8.3 & $27.9 \mathrm{~d}$ \\
\hline & $25 / 6$ & 23.0 & 5.0 & 8.3 & $36.3 \mathrm{bc}$ \\
\hline & $25 / 12$ & 30.0 & 6.6 & 8.3 & $44.9 \mathrm{a}$ \\
\hline & $50 / 6$ & 25.0 & 3.3 & 13.3 & $41.6 \mathrm{ab}$ \\
\hline & $50 / 12$ & 21.0 & 3.3 & 8.3 & $32.6 \mathrm{~cd}$ \\
\hline
\end{tabular}

${ }^{2}$ Each fruit was classified by the primary defect (soft, shrivel, or decay).

${ }^{y}$ End of marketable life: total defects $>15 \%$.

${ }^{x}$ Means with different letters within the column and for the same storage time are significantly different according to Duncan's multiple range test $(P<0.05)$. 
Table 3. Appearance of grape tomato defects under simulated commercial handling conditions. Fruit pretreated in air (control) or 1-MCP $\left(1 \mu \mathrm{L} \cdot \mathrm{L}^{-1}\right)$ for $24 \mathrm{~h}$ at 13 or $20^{\circ} \mathrm{C}$, followed by storage at $13{ }^{\circ} \mathrm{C}$ for $4 \mathrm{~d}$ and transfer to $20^{\circ} \mathrm{C}$ until end of marketable life (Expt. 3).

\begin{tabular}{lccccc}
\hline $\begin{array}{l}\text { Storage } \\
\text { time } \\
(\mathrm{d})\end{array}$ & $\begin{array}{c}\text { Pretreatment } \\
\text { conditions }\end{array}$ & $\begin{array}{c}\text { Soft } \\
(\%)\end{array}$ & $\begin{array}{c}\text { Shrivel } \\
(\%)\end{array}$ & $\begin{array}{c}\text { Decay } \\
(\%)\end{array}$ & $\begin{array}{c}\text { Total } \\
\text { defects }^{\mathrm{y}} \\
(\%)\end{array}$ \\
\hline 6 & Control, $\left.13{ }^{\circ} \mathrm{C}\right)$ & 0 & 1.6 & 0 & $1.6 \mathrm{a} \mathrm{a}^{\mathrm{x}}$ \\
& $1-\mathrm{MCP}, 13^{\circ} \mathrm{C}$ & 1.6 & 0 & 0 & $1.6 \mathrm{a}$ \\
& Control, $20^{\circ} \mathrm{C}$ & 0 & 5.0 & 1.6 & $5.6 \mathrm{ab}$ \\
7 & $1-\mathrm{MCP}, 20^{\circ} \mathrm{C}$ & 1.6 & 0 & 0 & $1.6 \mathrm{a}$ \\
& Control, $13^{\circ} \mathrm{C}$ & 16.0 & 1.6 & 1.6 & $19.2 \mathrm{a}$ \\
& $1-\mathrm{MCP}, 13^{\circ} \mathrm{C}$ & 8.3 & 0 & 1.6 & $9.9 \mathrm{~b}$ \\
& Control, $20^{\circ} \mathrm{C}$ & 10.0 & 5.0 & 3.3 & $18.3 \mathrm{a}$ \\
8 & $1-\mathrm{MCP}, 20^{\circ} \mathrm{C}$ & 10.0 & 3.3 & 0 & $13.3 \mathrm{~b}$ \\
& $1-\mathrm{MCP}, 13^{\circ} \mathrm{C}$ & 15.0 & 1.6 & 1.6 & $18.2 \mathrm{~b}$ \\
& $1-\mathrm{MCP}, 20^{\circ} \mathrm{C}$ & 25.0 & 3.3 & 0 & $28.3 \mathrm{a}$ \\
\hline
\end{tabular}

${ }^{2}$ Each fruit was classified by the primary defect (soft, shrivel, or decay).

${ }^{y}$ End of marketable life: total defects $>15 \%$.

${ }^{\mathrm{x}}$ Means with different letters within the column and for the same storage time are significantly different according to Duncan's multiple range test $(P<0.05)$.

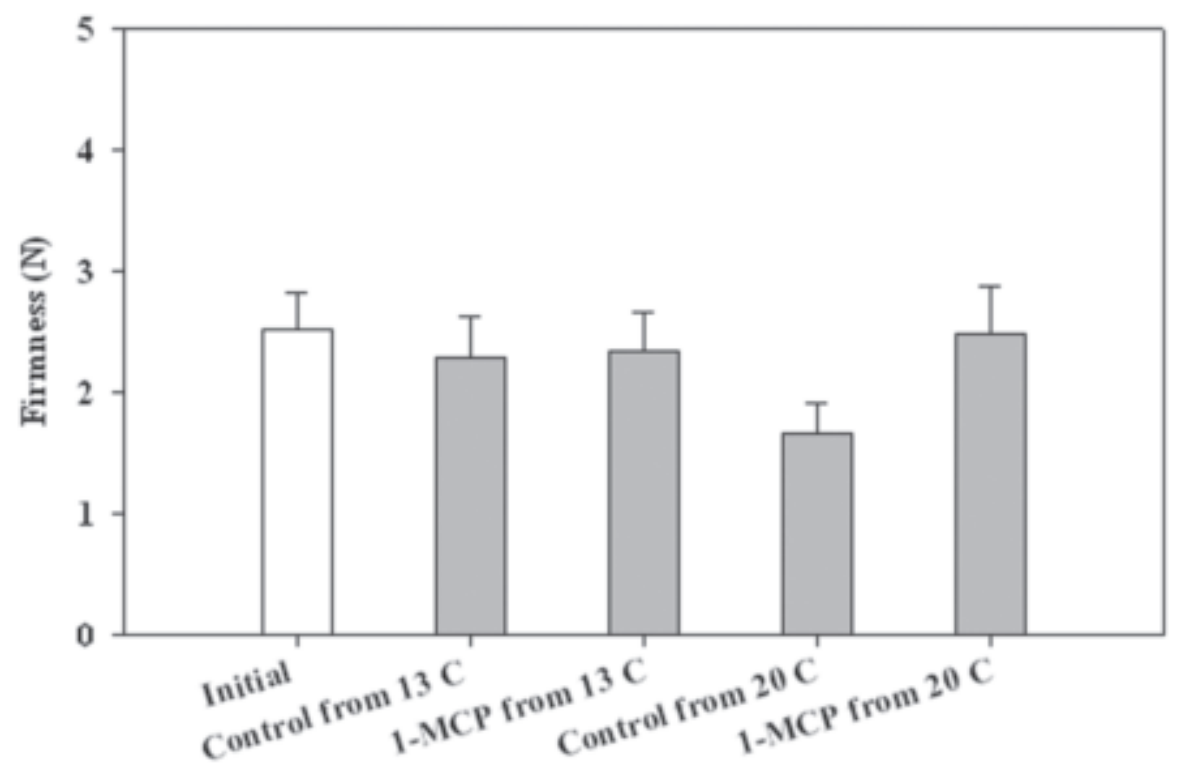

Treatunents

Fig. 3. Firmness (N) of full-red harvested fruit at the end of marketable life ( $\pm 1-\mathrm{MCP}$ pretreatment: $1 \mu \mathrm{L} \cdot \mathrm{L}^{-1}$ at 13 or $20^{\circ} \mathrm{C}$ for $24 \mathrm{~h}$, storage at $13^{\circ} \mathrm{C}$ for $4 \mathrm{~d}$, then transfer to $20^{\circ} \mathrm{C}$ ) (Expt. 3 ).

loss $(8 \%)$, external/internal color $\left(38^{\circ} / 60^{\circ}\right.$ hue angle), SSC $\left(6.3^{\circ} \mathrm{Brix}\right)$, TTA $(0.65 \%)$, or $\mathrm{pH}$ (4.3) (data not shown).

Experiment 3. Simulated commercial handling offull-red harvested grape tomatoes pretreated with $1 \mu L \cdot L^{-1} 1-M C P$. Since there were few differences in quality parameters due to the 1-MCP concentration/exposure time regimes in Expt. 2, the final study used one 1 -MCP concentration $\left(1 \mu \mathrm{L} \cdot \mathrm{L}^{-1}\right.$ for $24 \mathrm{~h}$ ) and two pretreatment-storage temperature regimes $\left(13,20^{\circ} \mathrm{C}\right)$.

As in previous tests, control tomatoes became unmarketable 1 d before the 1-MCP treated tomatoes; however in this test both treatments lasted $1 \mathrm{~d}$ longer than in the previous tests (Table 3) Softening was again the main limiting factor, increasing dramatically from day 6 to day 7 . Shriveling symptoms due to water loss were observed on control fruit on day 6 , whereas fruit pretreated $1-\mathrm{MCP}$ at $13{ }^{\circ} \mathrm{C}$ exhibited these symptoms on day 7 and fruit pretreated 1-MCP at $20^{\circ} \mathrm{C}$ on day $8.1-\mathrm{MCP}$ neither promoted nor retarded decay development in grape tomatoes harvested at either ripeness stage. Fruit pretreated with air at $20^{\circ} \mathrm{C}$ as a control softened significantly during storage (from 2.5 to $1.6 \mathrm{~N}$ ), whereas the other treatments remained firm(Fig. 3 . Weight loss ranged from $5 \%$ to $6 \%$ and was not affected by 1-MCP treatment or by pretreatment temperature $\left(13\right.$ or $\left.20^{\circ} \mathrm{C}\right)$ (data not shown). External and internal hue angles were similar to respective values in Expts. 1 and 2 (data not shown). There were no significant differences due to pretreatment for soluble solids content (6.7\%), TTA (0.76) or $\mathrm{pH}(4.4)$ after storage (data not shown).

\section{Discussion}

Grape tomatoes harvested at light-red and full-red stages and treated with 1-MCP (1 $\mu \mathrm{L} \cdot \mathrm{L}^{-1}$ for $24 \mathrm{~h}$ ) had suppressed decline in the respiration rate during subsequent storage at 20 ${ }^{\circ} \mathrm{C}$, whereas the rate in untreated fruit gradually decreased during this time (Fig. 1). 'Clarion' tomatoes (round type) treated at full-ripe stage (stage not defined by authors) with 10 , 20 or $100 \mu \mathrm{L} \cdot \mathrm{L}^{-1} 1-\mathrm{MCP}$ at $20^{\circ} \mathrm{C}$ for $2 \mathrm{~h}$ had lower respiration rates after 5 or $8 \mathrm{~d}$ at $20^{\circ} \mathrm{C}$ than untreated fruit (Wills and $\mathrm{Ku}, 2002$ ). The postclimacteric suppression in the respiration decline and/or suppression of respiration reveal that ethylene regulates respiration in tomatoes even at advanced stages of maturation.

In the first experiment ethylene production of untreated light-red and full-red harvested fruit declined approximately $50 \%$ during storage at $20^{\circ} \mathrm{C} .1-\mathrm{MCP}$ pretreatment significantly suppressed the decline in ethylene production in full-red harvested fruit(Fig. 2B); however in light-red harvested fruit, ethylene production rate and pattern were similar, irrespective of the treatments (Fig. 2A). This is similar to results reported in fully ripe 'Clarion' tomatoes after $5 \mathrm{~d}$ at $20^{\circ} \mathrm{C}$ (Wills and $\mathrm{Ku}, 2002$ ). However, Hoeberichts et al. (2002) found no effect of 1MCP treatment ( 50 to $150 \mathrm{~nL} \cdot \mathrm{L}^{-1}$ for $20 \mathrm{~h}$ at 20 ${ }^{\circ} \mathrm{C}$ ) on ethylene production of full-red tomato ('Prisca') during storage at $20^{\circ} \mathrm{C}$.

In the present study grape tomato quality was minimally affected by treatment with 1-MCP (Tables 2 and 3). The 1-MCP treatment regimes used in these experiments were relatively equivalent in extending marketable life. Increased 1-MCP concentration (from 1 $\mu \mathrm{L} \cdot \mathrm{L}^{-1}$ to 5,25 or $\left.50 \mu \mathrm{L} \cdot \mathrm{L}^{-1}\right)$ and the concomitant decrease in exposure time (from $24 \mathrm{~h}$ to 12 or $6 \mathrm{~h}$ ) did not increase marketable life, did not affect the incidence of defects and did not significantly affect quality parameters. However, fully ripe 'Clarion' tomatoes responded to higher 1-MCP concentrations (20 or 100 $\mu \mathrm{L} \cdot \mathrm{L}^{-1}$ for $2 \mathrm{~h}$ at $20^{\circ} \mathrm{C}$ ) compared to $1 \mu \mathrm{L} \cdot \mathrm{L}^{-1}$ by extending storage life from 16 to $21 \mathrm{~d}$ (Wills and $\mathrm{Ku}, 2002)$. In the present study, 1-MCP extended the storage life of full-red grape tomatoes by only $1 \mathrm{~d}$ (from 6 to $7 \mathrm{~d}$ or from 7 to $8 \mathrm{~d}$ ), indicating that 1 -MCP efficacy on tomatoes is strongly cultivar dependent.

Full-red harvested grape tomatoes treated with several 1-MCP concentrations for 6 or 12 $\mathrm{h}$ had similar marketable life, firmness, color, soluble solids content, $\mathrm{pH}$ and TTA, suggesting that $1-\mathrm{MCP}$ concentrations greater than 1 $\mu \mathrm{L} \cdot \mathrm{L}^{-1}$ may be applied to grape tomatoes for shorter durations if necessary. Wills and $\mathrm{Ku}$ (2002) noted that $1-\mathrm{MCP}$ treatment at $5 \mu \mathrm{L} \cdot \mathrm{L}^{-1}$ for $2 \mathrm{~h}$ at $20^{\circ} \mathrm{C}$ was sufficient to slow ripening in fully ripe tomato. In our tests, the effects of 1-MCP treatments to full-red harvested grape tomatoes at $13{ }^{\circ} \mathrm{C}$ were similar to fruit treated at $20^{\circ} \mathrm{C}$; thus tomatoes could be treated with $1-\mathrm{MCP}$ at $13{ }^{\circ} \mathrm{C}$ with the additional benefit of delayed ripening due to the cooler storage temperature.

Grape tomatoes pretreated with 1-MCP (1 $\mu \mathrm{L} \cdot \mathrm{L}^{-1}$ at $20^{\circ} \mathrm{C}$ for $24 \mathrm{~h}$ ) (Expt. 3) were firmer at the end of marketable life compared with untreated fruit held at $20{ }^{\circ} \mathrm{C}$ (Fig. 3). Hoeberichts et al. (2002) noted insignificant effects of 1-MCP on firmness in light-red and full-red tomatoes. However, Mir et al. (2004) reported that $1-\mathrm{MCP}\left(250 \mathrm{~nL} \cdot \mathrm{L}^{-1}\right.$ at room temperature for $16 \mathrm{~h}$ ) applied to light-red and full-red romatype tomato ('Plum Dandy') delayed softening during $11 \mathrm{~d}$ of storage at $22^{\circ} \mathrm{C}$. 
Delays in ripening due to $1-\mathrm{MCP}$ treatment did not significantly affect the color (hue angle) of either the surface or internal tissues of light-red or full-red harvested grape tomato. Lycopene accumulation has been reported to decrease as ripening progresses (Mostofi et al., 2003). Hoberichts et al. (2002) and Mir et al. (2004) showed that 1-MCP suppressed red color development (hue angle) when applied to light-red tomatoes but not when applied to full-red fruit.

In these tests no changes in soluble solids content or $\mathrm{pH}$ were observed for 1-MCPtreated fruit from either harvest maturity during storage at $20^{\circ} \mathrm{C}$. Wills and $\mathrm{Ku}$ (2002) reported, however, that the decrease in TTA was suppressed in fully ripe tomatoes treated with 1-MCP compared to untreated fruit. The present study also confirmed that soluble solids content and TTA were higher for fruit harvested at the full-red stage compared to fruit harvested at the light-red stage. Roberts et al. (2002) reported that soluble solids content was significantly higher for grape tomatoes harvested at full-red stage compared to those harvested breaker/turning ( $10 \%$ to $30 \%$ red) and ripened at either 13 or $20^{\circ} \mathrm{C}$. Therefore, for best flavor grape tomato should be harvested at or close to full-red stage.

1-MCP concentrations greater than $1 \mu \mathrm{L} \cdot \mathrm{L}^{-1}$ $\left(5,25\right.$, or $\left.50 \mu \mathrm{L} \cdot \mathrm{L}^{-1}\right)$ did not have a significant effect on the parameters measured in the present study, suggesting that the saturation response to 1 -MCP in ripe grape tomato is $\leq 1 \mu \mathrm{L} \cdot \mathrm{L}^{-1}$. Mir et al. (2004) concluded that 1-MCP saturation in roma-type tomatoes ranged from 0.25 to 1 $\mu \mathrm{L} \cdot \mathrm{L}^{-1}$ for $16 \mathrm{~h}$ at $22^{\circ} \mathrm{C}$.

For best quality under commercial handling conditions, grape tomatoes should be harvested at or near the full-red stage. The 1-d extension of postharvest life by 1-MCP treatment at 13 or $20^{\circ} \mathrm{C}$ may be commercially viable. Postharvest life may be further extended by employment of rapid cooling techniques and precise temperature management to make treatment with 1-MCP more effective.

\section{Literature Cited}

Blankenship S.M. and J.M. Dole. 2003. 1-methylcyclopropene: A review. Postharvest Biol. Technol. 28:1-25.

Ergun, M. and D.J. Huber. 2004. Suppression of Ethylene Perception Extends Shelf-life and Quality of 'Sunrise Solo' Papaya Fruit at both Pre-ripe and Ripe Stages of Development. Europ. J. Hort. Sci. 69:184-192.

Ergun, M., S.A. Sargent, A.J. Fox, J.H. Crane, and D.J.Huber. 2005. Ripening and quality responses of mamey sapote fruit to postharvest wax and 1-methylcycloproene treatments. Postharvest Biol. Technol. 36:127-14.

Geeson, J.D., K.M. Browne, K. Maddison, J. Shepherd, and F. Guaraldi. 1985. Modified atmosphere packing to extend the storage-life of tomatoes. J. Food Technol. 20:339-349.

Hardenburg, R.E., A.E. Watada, and C.Y. Wang. 1986. The commercial storage of fruits, vegetables, and florist and nursery stocks. Agricultural handbook 66. USDA Agr. Hndbk. 16.

Hobson, G.E., P. Adams, and T.J. Dixon. 1983. Assessing the color of tomato fruit during ripening. J. Sci. Food Agr. 34:286-292.

Hoeberichts, F.A., L.H.W. van der Plas, and E.J. Woltering. 2002. Ethylene perception is required for the expression of tomato ripening related genes and associated physiological changes even at advanced stages of ripening. Postharvest Biol. Technol. 26(2):125-133.

Hurr, B.M, D.J. Huber, and J.H. Lee. 2005. Differential responses in color changes and softening of 'Florida 47 ' tomato fruit treated at green and advanced ripening stages with the ethylene antagonist 1-methylcyclopropene. HortTechnology 15:617-622.

Janse, J. 1995. Flavour of tomatoes, p. 179-194. In, F. Weihenstephan(ed.). Deutschegesselschaft für qualitätsforschung-planzliche nachrungsmittele. V. XXX. Vortragstatung 'Geschmackstoffe in pflanzlichen nachrungsmittlen'.

Kader, A.A., L.L. Morris, M.A. Stevens, and M. Albright-Holton. 1978. Composition and flavor quality of fresh- market tomatoes as influenced by some postharvest handling procedures. J. Amer. Soc. Hort. Sci. 103:6-13.

Liu, Y., X.Z. Hua, and L.N. Guo. 1989. Effect of 2,5norbornadiene on the ripening and production of ethylene in tomato fruits, p. 101-108. In: H. Clijsters, M. DeProft, R. Marcella, and V. Poucke (eds.). Biochemical and physiological aspects of ethylene production in lower and higher plants. Kluwer Academic Publ.. Boston.

Malundo, T.M.M., R.L. Shewfelt, and J.W. Scott. 1995. Flavor quality of fresh tomato (Lycopersicon escelentum Mill.) as affected by sugar and acid levels. Postharvest Biol. Technol. 6:103-110.

Maul, F., S.A. Sargent, C.A. Sims, E.A. Baldwin, M.D. Balaban, and D.J. Huber. 2000. Tomato flavor and aroma quality as affected by storage temperature. J. Food Sci. 65(7):1218-1237.

McGuire, R.G. 1992. Reporting of objective color measurements. HortScience 27:1254-1255.

Mir, N., M. Canoles, R. Beaudry, and C.P. Mehla. 2004. Inhibiting tomato ripening 1-methylcyclopropene. J. Amer. Soc. Hort. Sci. 129:112-120.

Moretti, C.L., S.A. Sargent, C.A. Sims, and R. Puschmann. 1997. Flavor alteration in tomao fruit due to internal bruising. Proc. Fla. State. Hort. Soc. 110:195-197.

Moretti, C.L., S.A. Sargent, D.J. Huber, A.G. Calbo, and R. Puschmann. 1998. Chemical composition and physical properties of pericarp, locule, and placental tissues of tomatoes with internal bruising. J. Amer. Soc. Hort. Sci. 123(4):665-660.

Mostofi, Y., P.M.A. Toivonen, H. Lessani, M. Babalar, and C. Lu. 2003. Effects of 1-methycyclopropene on ripening of greenhouse tomatoes at three storage temperatures. Postharvest Biol. Technol. 27:285-292.

Roberts, P.K, S.A. Sargent, andA.J. Fox. 2002. Effect of storage temperature on ripening and postharvest quality of grape and mini-pear tomatoes. Proc. Fla. State. Hort. Soc. 115:80-84.

Sisler, E.C and N. Lallu. 1994. Effect of diazocyclopentadiene (DACP) on tomato fruits harvested at different ripening stages. Postharvest Biol. Technol. 4:245-254.

Tucker, G.A. and C.J. Brady. 1987. Silver ions interrupt tomato fruit ripening. J. Plant Physiol. 127:165-169.

U.S. Dept. of Agriculture. 1976. United States standard for grades of fresh market tomatoes. Agr. Mktg. Serv., Wash., D.C.

Wills, R.B.H. and V.V.V. Ku. 2002. Use of 1-MCP to extend the time to ripen of green tomatoes and postharvest life of ripe tomatoes. Postharvest Biol. Technol. 26:85-90.

Yang, S.F. and N.E. Hoffman. 1984. Ethylene biosynthesis and its regulation in higher plants. Annu. Rev. Plant Physiol. 35:155-189. 